\title{
ANALISIS PERTUMBUHAN TANAMAN RESTORASI DI TAMAN NASIONAL MATALAWA
}

\author{
Analysis of Restoration Plant Growth in Matalawa National Park
}

\author{
Suyogia Nur Azis ${ }^{1 *}$, Nurheni Wijayanto ${ }^{2}$, Arum Sekar Wulandari ${ }^{2}$
}

(Diterima Agustus 2019/Disetujui November 2020)

\begin{abstract}
Ecosystem restoration in Matalawa National Park is an effort to restore the condition of the forest so as to achieve the function of forest to maintain biodiversity. This research aims to analyze the biophysical influence against growth of plant restoration. The research was conducted in Manurara, Taman Mas, Tangairi and Waimanu. The object of the research consists of adinu plant (Melochia umbellata), cimung plant (Timonius timon), kihi plant (Canarium acutifolium), langaha plant (Planchonia valida) and mara plant (Tetrameles nudiflora). The experiment was analyzed by pearson correlation coefficient $(r)$ and t test. The results showed biophysical environmental factors have a very strong relationship with the growth of restoration plants in Matalawa National Park is phosphorus, CEC, pH and altitude of site. Besides, the growth of adinu plant is higher than other plants in open area conditions.
\end{abstract}

Keywords: biophysical, characteristics of plant species, forest restoration, national park

\section{PENDAHULUAN}

Taman Nasional Manupeu Tanah Daru dan Laiwangi Wanggameti (TN Matalawa) merupakan salah satu dari 50 Taman Nasional di Indonesia dengan luas \pm 134 998.09 ha yang terdiri atas Kawasan Manupeu Tanah Daru seluas \pm 87984.09 ha dan Kawasan Laiwangi Wanggameti seluas \pm 47014.00 ha. (BTN Matalawa 2017). Dalam mengelola kawasan, Balai TN Matalawa banyak mengalami gangguan dan permasalahan, meliputi: permasalahan pal batas, permasalahan status kawasan dan zonasi, permasalahan perladangan yang ada di dalam kawasan, permasalahan kebakaran hutan, illegal logging, perambahan serta pencurian potensi tumbuhan dan satwa liar (TSL). Selain itu, akibat budaya masyarakat membakar lahan untuk mendapatkan hijauan pakan ternak mengakibatkan kondisi hutan terdegradasi sehingga vegetasi di kawasan TN Matalawa didominasi oleh alang-alang (Imperata cylindrica). Menurut Friday et al. (2000), selain diakibatkan oleh kebakaran berkalikali, tumbuhnya padang alang-alang juga bisa diakibatkan oleh illegal logging dan perambahan oleh masyarakat. Kondisi habitat seperti ini mengancam keberadaan satwa yang ada di dalamnya.

Salah satu cara pengendalian alang-alang secara vegetatif yaitu melalui program restorasi (Pudjiharta $e t$ al. 2008). Restorasi adalah suatu upaya mengembalikan kondisi hutan sehingga tercapai fungsi hutan untuk menjaga keanekaragaman hayati. Pada tahun 2015, Balai TN Matalawa bekerjasama dengan pemerintah Jepang melalui Japan International Cooperation System (JICS) merestorasi kawasan yang tidak bervegetasi pepohonan

${ }^{1}$ Balai Taman Nasional Matalawa, Kementerian

Lingkungan Hidup dan Kehutanan

* Penulis korespondensi:

e-mail: sevchegia@gmail.com

${ }^{2}$ Dosen Departemen Silvikultur, Fakultas Kehutanan

Institut Pertanian Bogor selama 5 tahun (2015-2019). Program ini dilakukan pada areal seluas 250 ha dengan 4 site, yaitu: Taman Mas, Waimanu, Manurara dan Tangairi.

Hal yang perlu diperhatikan dalam pembangunan hutan pada awal restorasi kawasan yaitu pemilihan jenis tanaman. Dari jenis tanaman yang telah ditanam oleh JICS, terdapat perbedaan kecepatan pertumbuhan. Hal itu dimungkinkan akibat pengaruh respon jenis tanaman terhadap lingkungan biofisik. Lingkungan biofisik merupakan aspek utama yang menentukan keberhasilan program restorasi. Kesuburan tanah, vegetasi yang ada dan gangguan berulang dapat menghambat pertumbuhan tanaman restorasi (Lamb dan Gilmour 2003). Jenis tanaman restorasi yang ditanam di areal kawasan TN Matalawa meliputi 25 jenis lokal, seperti: adinu (Melochia umbellata), cimung (Timonius timon), kapaka (Sterculia foetida), kapulut (Ficus racemosa), kihi (Canarium acutifolium), langaha (Planchonia valida), mara (Tetrameles nudiflora), rita (Alstonia scholaris), surian (Toona sureni), dan lainnya. Jenis yang dipilih pada penelitian ini meliputi 5 jenis tanaman yang direkomendasikan oleh JICS. Jenis tersebut merupakan tanaman yang bibitnya tersedia pada persemaian masingmasing site dan ditanam pada seluruh site penanaman.

Penelitian dilakukan untuk menganalisis pengaruh biofisik terhadap pertumbuhan tanaman restorasi. Penelitian ini diharapkan dapat menyediakan data informasi jenis tanaman yang ideal ditanam pada awal kegiatan restorasi kawasan TN Matalawa.

\section{METODE PENELITIAN}

\section{Waktu dan Tempat Penelitian}

Penelitian dilaksanakan mulai bulan Oktober 2016 sampai Oktober 2017. Penelitian dilakukan di kawasan TN Matalawa, lokasi restorasi JICS yang meliputi 4 site, yaitu: Taman Mas, Manurara, Waimanu dan Tangairi. 


\section{Alat dan Bahan}

Alat yang digunakan pada penelitian ini meliputi: GPS, aplikasi ArcMap 10.3, peta kawasan TN Matalawa, termometer, RH meter, hellman, mesin potong rumput, cangkul, parang, linggis, bor tanah, pita ukur, meteran, kaliper, counter, penggaris, plastik sampel tanah, label, ajir, tally sheet, kamera dan alat tulis. Objek dalam penelitian ini adalah 5 tanaman restorasi, meliputi: adinu (M. umbellata), cimung (T. timon), kihi (C. acutifolium), langaha ( $P$. valida) dan mara (T. nudiflora).

\section{Prosedur Penelitian}

Lokasi penelitian dipilih karena kemudahan akses, lahan berupa areal terbuka, serta sering terjadi gangguan kebakaran dan illegal logging. Pada masing-masing site terdapat $3 \mathrm{plot} /$ petak pengamatan dengan ukuran 50 x 50 meter. Plot/petak tersebut sudah mencukupi untuk intensitas sampling 5\% dari luas setiap site (Miyakawa et al. 2014).

Pembersihan lahan dari alang-alang dilakukan menggunakan alat potong rumput dengan cara membentuk jalur tanam dengan lebar 2 meter. Ajir ditancapkan untuk memberi tanda pembuatan lubang tanam. Pembuatan lubang tanam dilakukan 2 minggu sebelum penanaman. Jarak antar jalur lubang tanam 3 meter dengan jarak antar lubang $3 \times 3$ meter, setiap lubang tanam diberikan pupuk kandang campuran kotoran babi dan kerbau $1 \mathrm{~kg}$.

Penanaman tanaman restorasi dilakukan pada awal musim penghujan dengan mengikuti lubang tanam yang telah dipersiapkan. Bibit yang siap tanam memiliki ciri kondisinya sehat, segar dan mempunyai tinggi lebih \pm 30 $\mathrm{cm}$. Tanaman restorasi ditanam secara acak di masingmasing site penanaman yang meliputi 25 jenis tanaman.

Kegiatan pemeliharaan tanaman restorasi meliputi penyulaman, penyiangan dan pengendalian dari gangguan kebakaran dan ternak liar. Penyulaman dilakukan ketika tanaman berumur 1 bulan setelah tanam. Penyulaman dilakukan terhadap tanaman yang tidak tumbuh atau tumbuh abnormal. Penyiangan dilakukan setiap 6 bulan sekali. Penyiangan terhadap alang-alang dilakukan menggunakan alat pemotong rumput.

\section{Metode Pengumpulan Data dan Analisis Data}

Data yang dikumpulkan terdiri atas pertumbuhan dimensi tanaman restorasi, sifat tanah, pengamatan terhadap mikro klimat. Pengambilan sampel tanah menggunakan metode systematic sampling (SyS). Contoh tanah ini digunakan untuk pengamatan sifat kimia dan sifat fisik tanah. Sifat kimia tanah seperti $\mathrm{pH}$, KTK, kandungan nutrisi berupa C-organik, N, P tersedia dan unsur hara lain dianalisis di laboratorium.

Pengukuran suhu, kelembaban, curah hujan dan unsur mikro klimat lainnya dilakukan selama penelitian di pondok restorasi JICS. Alat pengukuran unsur iklim menggunakan peralatan yang dikembangkan oleh JICS. Adapun rekapitulasi keseluruhan data kondisi lingkungan biofsik yang akan diambil tersaji pada Tabel 1.

Pengamatan terhadap pertumbuhan tanaman restorasi di TN Matalawa dilakukan setiap 6 bulan sekali meliputi 3 kali pengamatan (Miyakawa et al. 2014). Peubah yang diamati meliputi pengukuran tinggi tanaman, diameter batang dan persentasi hidup tanaman.

Analisis data menggunakan Koefisien Korelasi Pearson (r) untuk melihat peubah bebas yang mempunyai hubungan paling erat terhadap pertumbuhan tanaman restorasi. Metode ini digunakan untuk mengetahui hubungan antara peubah bebas $\left(\mathrm{X}_{1}, \mathrm{X}_{2}, \ldots, \mathrm{X}_{\mathrm{n}}\right)$ dengan peubah tak bebas pertumbuhan tanaman restorasi (Y). Model matematikanya menurut Walpole (1995) adalah sebagai berikut:

$$
r=\frac{n \sum_{i=1}^{n} x_{i} y_{i}-\left(\sum_{i=1}^{n} x_{i} \sum_{i=1}^{n} y_{i}\right)}{\sqrt{\left[n \sum_{i=1}^{n} x_{i}{ }^{2}-\left(\sum_{i=1}^{n} x_{i}\right)^{2}\right]\left[n \sum_{i=1}^{n} y_{i}{ }^{2}-\left(\sum_{i=1}^{n} y_{i}\right)^{2}\right]}}
$$

Keterangan:

$\mathrm{r}=$ koefisien korelasi $\quad \mathrm{y}=$ peubah tak bebas

$\mathrm{x}=$ peubah bebas $\quad \mathrm{n}=$ jumlah sampel

Nilai $r$ berkisar antara 0 sampai 1 , nilai semakin mendekati 1 berarti hubungan yang terjadi semakin kuat, sebaliknya nilai semakin mendekati 0 maka hubungan yang terjadi semakin lemah. Kriteria korelasi antara dua variabel menurut Sarwono (2006) meliputi: sangat kuat $(0.75<\mathrm{r} \leq 1)$, kuat $(0.50<\mathrm{r} \leq 0.75)$, cukup kuat $(0.25<$ $\mathrm{r} \leq 0.50)$, lemah $(0<\mathrm{r} \leq 0.25)$, dan tidak ada korelasi ( $\mathrm{r}$ $=0$ ). Peubah bebas yang dipilih dalam penelitian ini meliputi: pH, C-organik, N-total, $\mathrm{P}$ tersedia, KTK, ketinggian tempat. Faktor iklim meliputi suhu, kelembaban, curah hujan dan intensitas cahaya matahari bukan variabel bebas pada penelitian ini karena dilakukan pada satu site untuk mewakili seluruh site lokasi restorasi.

Uji $t$ digunakan untuk mengetahui perbedaan pertumbuhan tanaman antar lokasi tanam. Model

Tabel 1 Pengamatan kondisi biofisik dan pertumbuhan tanaman

\begin{tabular}{|c|c|c|c|c|}
\hline No. & Peubah & Satuan & Waktu pengamatan & Alat yang digunakan \\
\hline 1. & Pengamatan kondisi biofisik & & & \\
\hline a. & Sifat tanah & - & Sebelum penanaman & Plastik sampel/ lab. \\
\hline b. & Ketinggian tempat & mdpl & Sebelum penanaman & $\begin{array}{l}\text { GPS \& Peta kontur TN } \\
\text { Matalawa }\end{array}$ \\
\hline 2. & Pertumbuhan tanaman & & & \\
\hline a. & Tinggi & $\mathrm{cm}$ & $1 \mathrm{kali} / 6$ bulan & Meteran \\
\hline b. & Diameter & $\mathrm{mm}$ & 1 kali / 6 bulan & Kaliper \\
\hline c. & $\%$ tumbuh & anakan & 1 kali $/ 6$ bulan & Counter \\
\hline
\end{tabular}


persamaan menurut Walpole (1995) adalah sebagai berikut:

$$
t=\frac{\left(\overline{x_{a}}-\overline{x_{b}}\right)-\left(\overline{\mu_{a}}-\overline{\mu_{b}}\right)}{\sqrt{\frac{s b_{a}^{2}}{n_{a}}+\frac{s b_{b}^{2}}{n_{b}}}}
$$

Keterangan:

$\mathrm{X}_{\mathrm{a}}=$ rataan sampel $\mathrm{I}_{0} \quad \mathrm{sb}_{\mathrm{a}} \quad$ = simpangan baku $\mathrm{I}_{0}$

$\mathrm{X}_{\mathrm{b}}=$ rataan sampel $\mathrm{I}_{1} \quad \mathrm{sb}_{\mathrm{b}} \quad$ = simpangan baku $\mathrm{I}_{1}$

$\mu_{\mathrm{a}}=$ rataan populasi $\mathrm{I}_{0} \quad \mathrm{n}_{\mathrm{a}} \quad=$ jumlah sampel $\mathrm{I}_{0}$

$\mu_{\mathrm{b}}=$ rataan populasi $\mathrm{I}_{1} \quad \mathrm{n}_{\mathrm{b}} \quad$ = jumlah sampel $\mathrm{I}_{1}$

Perhitungan persentase hidup tanaman dilakukan pada setiap jenis tanaman pada plot/petak pengamatan dengan perhitungan sebagai berikut:

$$
\% \text { hidup }=\frac{\text { jumlah tanaman hidup }}{\text { total tanaman ditanam }} \times 100 \%
$$

\section{HASIL DAN PEMBAHASAN}

Lokasi penelitian ini merupakan areal restorasi JICS TN Matalawa memiliki dua musim, yaitu kemarau dan hujan. Iklimnya tergolong kering dengan curah hujan $4.87 \mathrm{~mm} / \mathrm{hari}, \mathrm{RH} 42.48 \%$ dan suhu rata-rata harian $29.67{ }^{\circ} \mathrm{C}$. Kondisi tanah dan ketinggian tempat pada masing-masing site penanaman berbeda sebagaimana tersaji pada Tabel 2 .

Jenis yang dipilih sebagai objek penelitian yaitu 5 jenis tanaman restorasi meliputi: adinu (M. umbellata), cimung ( $T$. timon), kihi ( $C$. acutifolium), langaha $(P$. valida) dan mara (T. nudiflora). Menurut Wagner et al. (1999), tanaman adinu (M. umbellata) merupakan tanaman intoleran dengan tinggi bisa mencapai 45 meter, bersifat fast growing sehingga biasa dimanfaatkan untuk merestorasi hutan. Tanaman adinu biasa dimanfaatkan sebagai tanaman peneduh tanaman kopi.

Berdasarkan uji t (Gambar 1) untuk melihat perbedaan pertumbuhan tinggi tanaman antar site, Pertumbuhan tinggi tanaman adinu yang paling besar berada di Manurara. Hal tersebut juga terjadi untuk jenis kihi dan langaha. Namun, pertumbuhan tanaman adinu di Manurara tidak berbeda nyata dengan di Taman Mas, dan pertumbuhan tanaman kihi tidak berbeda nyata dengan di Tangairi. Pertumbuhan tanaman cimung dan mara paling besar berada di Manurara dan Tangairi. Pertumbuhan tanaman adinu berhubungan sangat kuat dengan KTK, $\mathrm{pH}$ dan ketersediaan unsur hara fosfor. Hubungan tersebut terlihat searah seperti tersaji pada Gambar 2.

KTK, pH serta ketersediaan unsur hara khususnya $\mathrm{N}$ dan $\mathrm{P}$ merupakan variabel yang saling berhubungan sangat kuat seperti tersaji pada Tabel 3. Hal tersebut sesuai dengan hasil kajian Munawar (2011), bahwa muatan partikel tanah sangat berhubungan dengan $\mathrm{pH}$ tanah. Hal ini berpengaruh terhadap kemampuan tanah dalam menjerap kation. Besar-kecilnya KTK dapat berpengaruh terhadap ketersediaan unsur hara yang dapat diserap oleh tanaman. Ada indikasi bahwa hal tersebut merupakan sistem dinamis terhadap kesuburan tanah. Penurunan atau peningkatan kesuburan dapat diakibatkan oleh perubahan $\mathrm{pH}$, KTK dan ketersediaan hara (Price 2006).

\begin{tabular}{|c|c|c|c|c|c|c|c|}
\hline No. & Lokasi & $\mathrm{pH}$ & $\begin{array}{c}\text { C-Org. } \\
(\%)\end{array}$ & $\begin{array}{c}\text { N Tot. } \\
(\%)\end{array}$ & $\begin{array}{c}\text { P Ters. } \\
(\mathrm{ppm})\end{array}$ & $\begin{array}{c}\mathrm{KTK} \\
\left(\mathrm{cmol}^{(+)} / \mathrm{kg}\right)\end{array}$ & $\begin{array}{c}\text { Ketinggian } \\
\text { (mdpl) }\end{array}$ \\
\hline 1. & Manurara & 5.66 & 4.13 & 0.34 & 4.96 & 48.43 & 350 \\
\hline 2. & Taman Mas & 5.21 & 3.57 & 0.22 & 3.76 & 12.68 & 600 \\
\hline 3. & Tangairi & 5.22 & 1.93 & 0.16 & 3.50 & 8.67 & 200 \\
\hline 4. & Waimanu & 5.36 & 4.49 & 0.31 & 3.33 & 18.49 & 400 \\
\hline
\end{tabular}

Tabel 2 Kondisi tanah dan ketinggian tempat lokasi penelitian
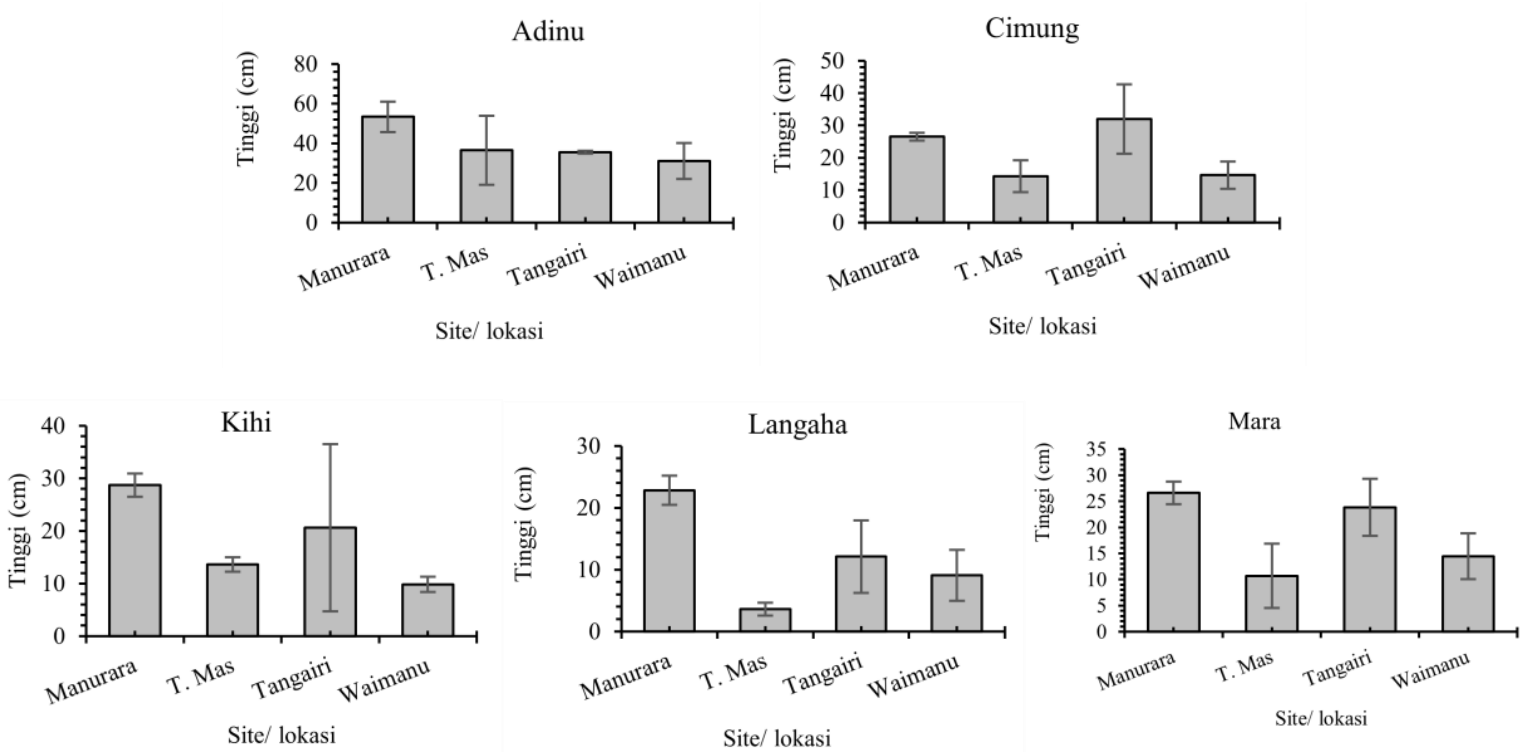

Gambar 1 Pertumbuhan tanaman restorasi pada masing-masing site penanaman 
Cimung (T. timon), kihi (C. acutifolium) dan langaha ( $P$. valida) merupakan jenis tanaman toleran. Cimung adalah tanaman yang tumbuh liar di kawasan TN Matalawa. Jenis ini tahan terhadap kebakaran. Selain itu, ranting dan daun yang masih hijau dapat membantu petugas TN Matalawa dalam kegiatan pemadaman. Cimung dikenal dengan ketimunan di beberapa daerah di Indonesia, meliputi: sekitar Cagar Biosfer Bukit Duabelas, TN Kerinci Seblat dan TN Wasur. Cimung dapat dimanfaatkan sebagai tanaman obat. Bagian tanaman yang dimanfaatkan mulai dari buah, daun, batang hingga kulitnya untuk berbagai penyakit, meliputi: diare, demam, pilek, batuk, sesak nafas, malaria, sakit gigi, sakit mata dan pendarahan (Widya et al. 2015). Jenis tanaman ini terancam kelestariannya. Umumnya, masyarakat masih belum mengenal manfaat dari cimung, sehingga belum membudidayakannya. Pada saat ini, pengawetan untuk menjamin kelestarian cimung hanya secara in situ yaitu di dalam kawasan Taman Nasional.

Hasil analisis korelasi pearson antara faktor biofisik dengan pertumbuhan cimung menunjukkan terdapat hubungan yang sangat kuat antara pertumbuhan tanaman cimung dengan ketinggian tempat. Koefisien korelasi antara keduanya bernilai negatif yang berarti apabila tanaman cimung ditanam pada tempat dengan ketinggian lebih rendah maka tingkat pertumbuhan tanaman akan lebih tinggi. Hubungan antara pertumbuhan tanaman cimung dengan ketinggian lokasi tanam tersaji pada Gambar 3. Pertumbuhan tanaman cimung paling tinggi berada di Tangairi dengan ketinggian 200 mdpl, sedangkan terendah berada di Taman Mas dengan ketinggian $600 \mathrm{mdpl}$

Kihi (C. acutifolium) merupakan jenis pohon hutan dari famili Burseraceae, tumbuh secara alami di Papua New Guinea, Maluku, Sulawesi dan Queensland (Australia). Tanaman ini tumbuh baik pada ketinggian 100 mdpl. Kihi pertama kali ditemukan oleh ahli botani Elmer D. Merrill pada tahun 1917 (Takeuchi 2000). Di Australia, C. acutifolium tumbuh secara alami di hutan dataran rendah dan hanya tersisa di wilayah tropis basah, sebelah timur laut Queensland. Status C. acutifolium menjadi jenis tanaman nasional yang dilindungi oleh pemerintah Queensland karena populasinya yang sudah sedikit (Queensland Government 2006). Berdasarkan Tabel 3, pertumbuhan tanaman kihi berhubungan sangat

Tabel 3 Koefisen korelasi biofisik terhadap pertumbuhan tanaman restorasi

\begin{tabular}{|c|c|c|c|c|c|c|}
\hline Variabel & $\mathrm{pH}$ & C-org & N-total & $\mathrm{P}$ & KTK & $\mathrm{H}$ \\
\hline C-org & 0.560 & & & & & \\
\hline N-total & $0.836^{*}$ & $0.918 *$ & & & & \\
\hline $\mathrm{P}$ & $0.852 *$ & 0.288 & 0.552 & & & \\
\hline KTK & $0.986^{*}$ & 0.547 & $0.808^{*}$ & $0.920 *$ & & \\
\hline $\mathrm{H}$ & -0.162 & 0.530 & 0.222 & -0.006 & -0.058 & \\
\hline Pertumbuhan adinu & $0.840^{*}$ & 0.196 & 0.489 & $0.994 *$ & $0.901 *$ & -0.107 \\
\hline Pertumbuhan cimung & 0.201 & -0.688 & -0.344 & 0.313 & 0.176 & $-0.862 *$ \\
\hline Pertumbuhan kihi & 0.669 & -0.204 & 0.161 & $-0.850 *$ & 0.707 & -0.467 \\
\hline Pertumbuhan langaha & $0.883^{*}$ & 0.118 & 0.500 & $-0.800 *$ & $0.854 *$ & -0.560 \\
\hline Pertumbuhan mara & 0.600 & -0.306 & 0.096 & -0.593 & 0.563 & $-0.806^{*}$ \\
\hline
\end{tabular}

(a)

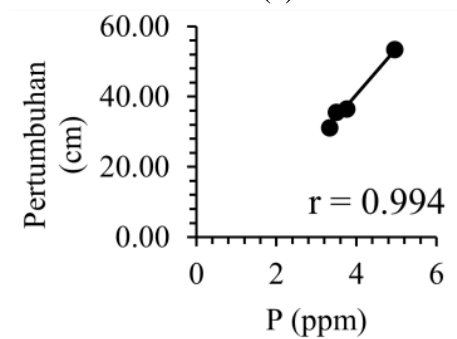

(b)

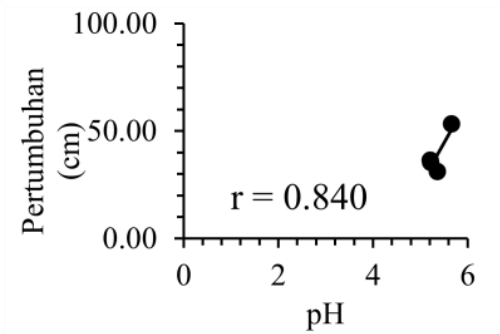

(c)

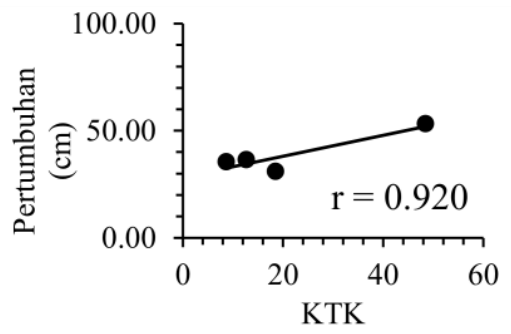

Gambar 2 Korelasi antara variabel bebas dengan pertumbuhan tanaman adinu: (a) P dengan pertumbuhan adinu,

(b) $\mathrm{pH}$ dengan dengan pertumbuhan adinu, (c) KTK dengan pertumbuhan adinu

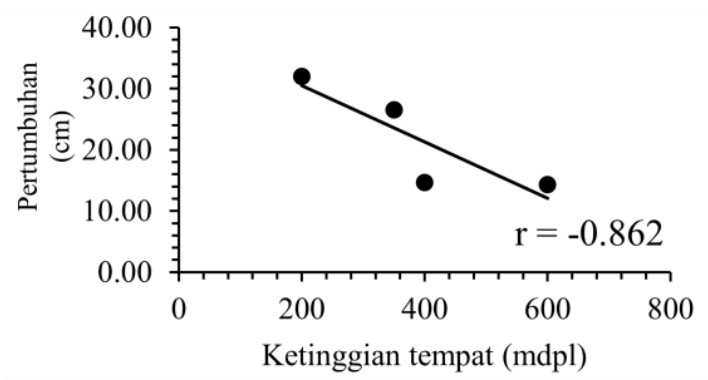

Gambar 3 Korelasi antara ketinggian tempat dengan pertumbuhan tanaman cimung

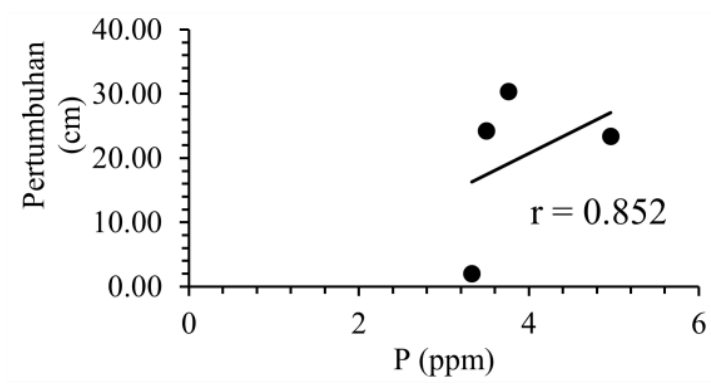

Gambar 4 Korelasi antara unsur $\mathrm{P}$ dengan pertumbuhan tanaman kihi 
kuat dengan variabel $\mathrm{P}$ dengan nilai koefisien korelasi (r) sebesar 0.850. Hubungan antara variabel $\mathrm{P}$ dengan pertumbuhan kihi tersaji pada Gambar 4.

Langaha $(P$. valida) merupakan tanaman berkayu keras dengan tinggi bisa mencapai 50 meter. Langaha termasuk ke dalam famili Lecythidaceae, dengan persebaran cukup luas di Indonesia. Langaha bisa dikenal dengan nama darah (Karo), putat (Sunda, Jawa dan Bali), butat (Madura), kutat (Bali). Langaha dapat tumbuh dengan baik di dataran rendah hingga ketinggian 1000 mdpl (Hardiyanto 2008). Secara morfologi, langaha berdaun tunggal, tipis seperti kertas, mengkilat, dengan tepi bergerigi (Shadily 1984).

Hasil analisis korelasi pearson antara faktor biofisik dan pertumbuhan langaha menunjukkan variabel bebas yang mempunyai hubungan sangat kuat dengan pertumbuhan tanaman langaha yaitu variabel $\mathrm{pH}$, KTK dan $\mathrm{P}$ dengan nilai koefisien korelasi (r) masing-masing sebesar $0.883,0.854$ dan 0.800. Gambar 5 tersaji hubungan yang positif antara variabel $\mathrm{pH}$, KTK dan $\mathrm{P}$ dengan pertumbuhan tanaman langaha.

Mara (T. nudiflora) adalah habitat kakatua jambul jingga (Cacatua sulphurea citrinocristata) yang merupakan satwa endemik di Pulau Sumba. Tanaman ini

(a)

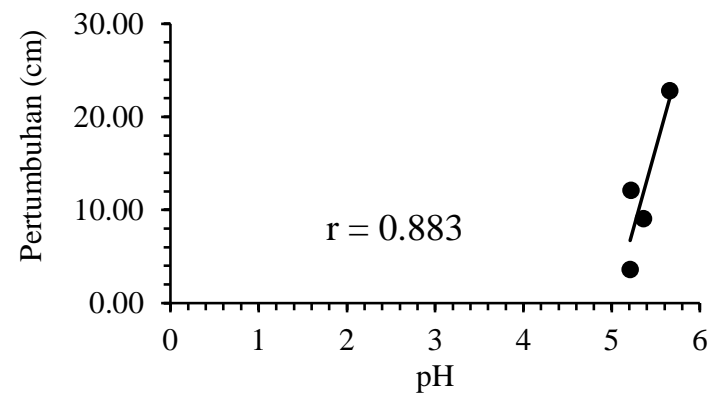

(b)
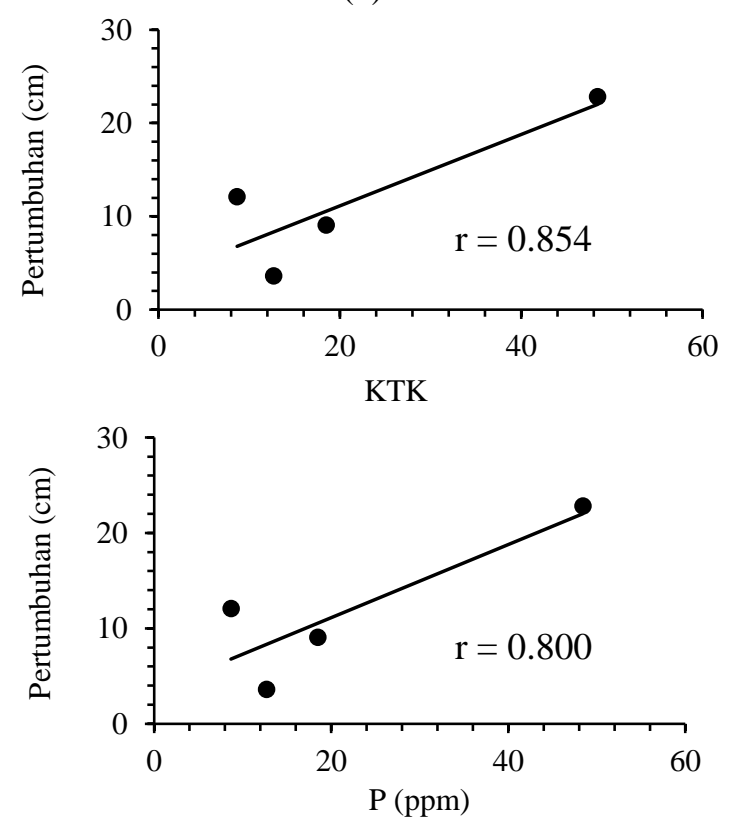

Gambar 5 Korelasi antara variabel bebas dengan pertumbuhan tanaman langaha: (a) $\mathrm{pH}$ dengan pertumbuhan langaha, (b) KTK dengan dengan pertumbuhan langaha, (c) $\mathrm{P}$ dengan pertumbuhan langaha menjadi tempat bersarang, berkembang biak dan beristirahat bagi satwa jenis tersebut (Hidayat dan Kayat 2014). Jenis tanaman ini dapat tumbuh baik di pegunungan maupun di lembah. Menurut Anugrah et al. (2017), mara merupakan pohon penyusun hutan lebat sebagai habitat 26 jenis burung di Hutan Lindung Register 25 Pematang Tanggang Kabupaten Tanggamus Lampung (Anugrah et al. 2017). Tinggi tanaman mara dapat mencapai lebih dari 20 meter dengan menempati stratum A di Blok Hutan Lodadi, TN Meru Betiri (Kalima 2008).

Faktor biofisik yang mempunyai hubungan paling kuat dengan pertumbuhan tanaman mara yaitu ketinggian tempat. Gambar 6 tersaji korelasi negatif antara ketinggian tempat dengan pertumbuhan tanaman mara. Tanaman mara dapat tumbuh dengan baik pada ketinggian $200 \mathrm{mdpl}$ dan $350 \mathrm{mdpl}$ apabila dibandingkan dengan tanaman yang ditanam pada ketinggian 400 dan 600 mdpl. Hal ini menunjukkan bahwa habitat tanaman mara berada di dataran rendah, sesuai dengan penelitian Kalima (2008), di mana tanaman mara banyak ditemukan di Blok Hutan Lodadi dengan ketinggian 0-200 mdpl.

Pertumbuhan tanaman adinu pada setiap site lebih tinggi dibandingkan dengan jenis lainnya seperti tersaji pada Gambar 7. Kondisi areal lahan penanaman yang masih terbuka memungkinkan bagi jenis-jenis intoleran (seperti adinu) untuk tumbuh lebih cepat dibandingkan dengan jenis toleran. Jenis intoleran sangat baik untuk kegiatan restorasi karena dapat mempercepat permulaan suksesi dan awal pembangunan hutan (Hooper et al. 2005; Gbetoho et al. 2017).

Berdasarkan hasil pengamatan di lapangan, adinu mempunyai morfologi berbatang keras dan mempunyai perakaran dalam. Selain itu, adinu mempunyai daun dengan ukuran lebih besar dan tebal dibandingkan dengan jenis lainnya. Lestari et al. (2008) mengemukakan bahwa tumbuhan intoleran memiliki ukuran daun lebih kecil, lebih tebal dan masa jenis tinggi sehingga dapat tumbuh lebih baik pada lokasi terbuka dan terkena matahari langsung. Pada umumnya jenis intoleran lebih tahan terhadap kondisi kelembaban tanah yang rendah seperti di kawasan TN Matalawa. Tanaman dapat beradaptasi terhadap overheating dan penggunaan air berlebihan dengan memiliki daun kecil dan tebal. Ukuran daun adinu yang tebal dan lebih lebar berpotensi memfiksasi karbon (konversi karbondioksida menjadi senyawa organik) lebih banyak daripada daun ukuran kecil. Ketersediaan air untuk pertumbuhan dapat

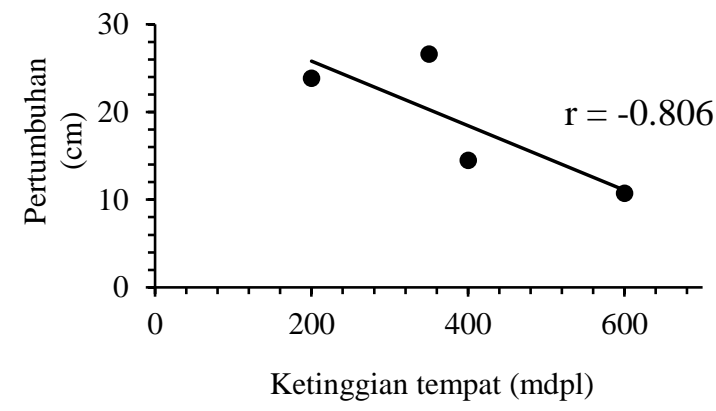

Gambar 6 Korelasi antara ketinggian tempat dengan pertumbuhan tanaman mara 
tercukupi dengan kondisi akar tunjang sehingga dapat menyerap air tanah lebih dalam.

Pertumbuhan tanaman cimung, kihi dan langaha relatif lebih lambat. Berdasarkan pengamatan di lapangan, tanaman tersebut memiliki ukuran daun yang lebih tipis. Hal ini adalah faktor penting bagi tanaman dalam merespon cahaya matahari yang diterima tanaman. Tanaman memiliki ambang batas terhadap intensitas cahaya yang diterima. Intensitas cahaya yang tinggi dapat merusak struktur kloroplas yang membantu proses metabolisme tanaman (Haryanti 2008). Selain itu, perakaran jenis ini relatif dangkal sehingga serapan hara dan air oleh tanaman lebih sedikit. Serapan hara dan air yang sedikit dapat membatasi pertumbuhan dan
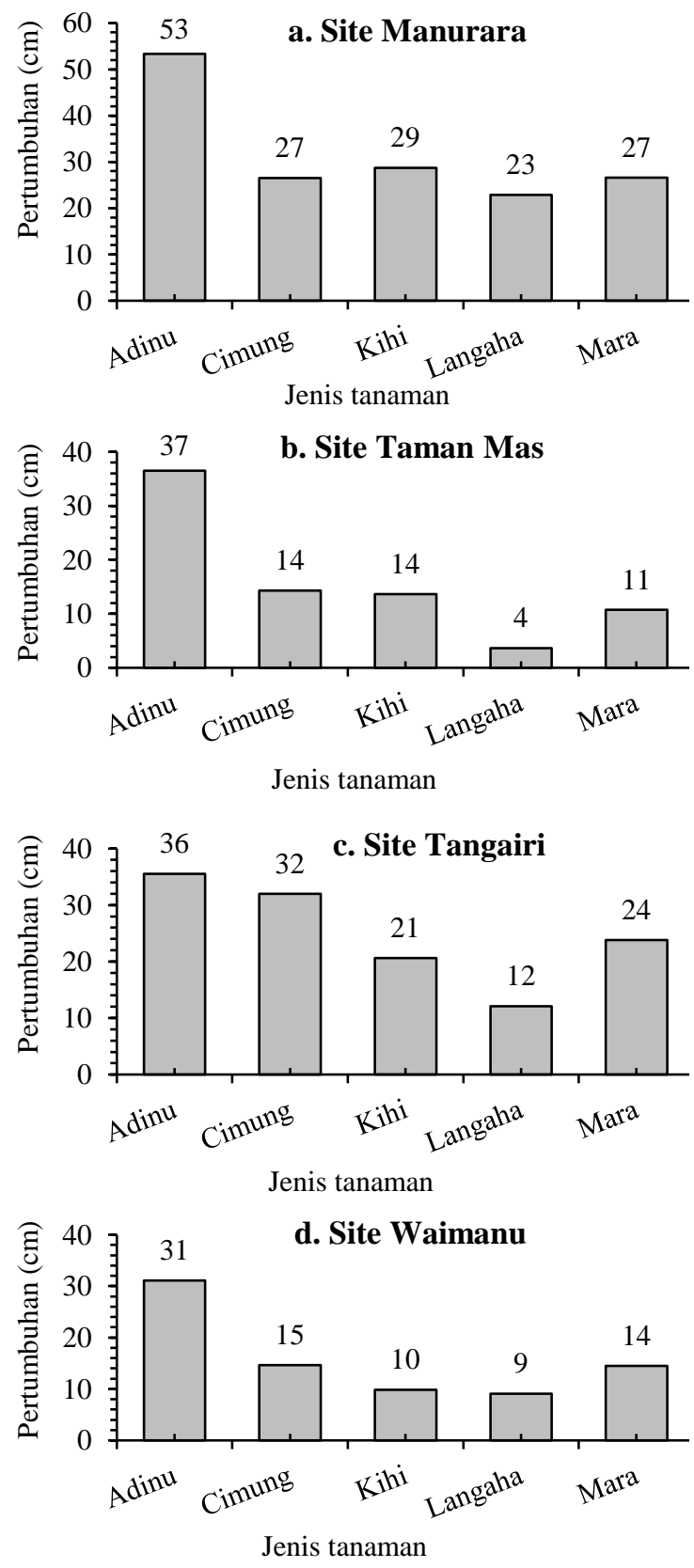

Gambar 7 Perbedaan pertumbuhan antar tanaman restorasi pada 4 site penanaman (Site: a. Site Manurara, b. Taman Mas, c. Tangairi, d. Waimanu) perkembangan tanaman. Respon tanaman terhadap serapan hara dan air dapat dilihat melalui aktivitas metabolisme, bentuk morfologi, tingkat pertumbuhan dan produktivitas tanaman (Solichatun 2005).

Gambar 8 menunjukkan bahwa semua jenis tanaman restorasi yang menjadi obyek penelitian ini dapat hidup dengan baik. Kegiatan penanaman jenis adinu, cimung, kihi, langaha dan mara di lokasi restorasi tergolong berhasil dengan persentase hidup $>65 \%$. Kegiatan pemeliharaan yang dilakukan oleh pihak JICS melalui monitoring, penyulaman dan penyiangan secara berkala merupakan salah satu kunci keberhasilan penanaman jenis tersebut. Selain itu, kegiatan patroli rutin dan pembuatan sekat bakar yang dilakukan oleh JICS juga menjadi faktor penting untuk menjamin keberhasilan kegiatan restorasi dari gangguan kebakaran dan penggembalaan ternak secara liar.

\section{SIMPULAN DAN SARAN}

\section{Simpulan}

Lingkungan biofisik yang mempunyai hubungan sangat kuat dengan pertumbuhan tanaman restorasi di TN Matalawa adalah unsur hara fosfor, KTK, pH dan ketinggian tempat. Ketinggian tempat berbanding terbalik dengan pertumbuhan tanaman restorasi. Hubungan yang sangat kuat terlihat pada pertumbuhan tanaman cimung ( $T$. timon) dan mara ( $T$. nudiflora). Berdasarakan penelitian ini, tanaman cimung dan mara tumbuh dengan baik pada dataran rendah dengan ketinggian 200-350 mdpl. Tanaman adinu ( $M$. umbellata) menunjukkan pertumbuhan paling tinggi di semua lokasi restorasi TN Matalawa. Berdasarkan persentase hidup tanaman, jenis adinu, cimung, kihi, langaha dan mara di lokasi restorasi TN Matalawa tergolong berhasil dengan persentase $>65 \%$.

\section{Saran}

Penelitian lanjutan untuk menganalisis pertumbuhan tanaman toleran (mara, kihi dan langaha) di bawah tajuk perlu dilakukan mengingat pertumbuhan tanaman tersebut tumbuh lambat di tempat terbuka. Selain itu, diperlukan kajian secara fisiologis terkait respon tanaman dalam menangkap cahaya yang diterima oleh tanaman restorasi.

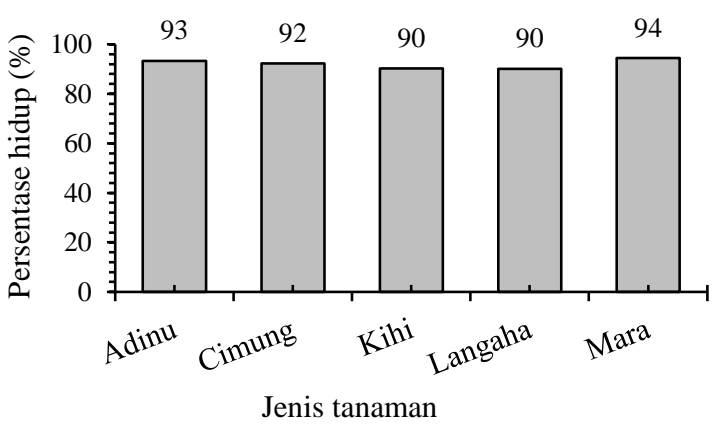

Gambar 8 Persentase hidup tanaman restorasi 


\section{DAFTAR PUSTAKA}

Anugrah KD, Setiawan A, Master J. 2017. Keanekaragaman spesies burung di Hutan Lindung Register 25 Pematang Tanggang Kabupaten Tanggamus Lampung. Jurnal Sylva Lestari. 5(1): 105-116.

BTN Matalawa. 2017. Laporan Kinerja (LKj) BTN Matalawa Tahun 2016. Waingapu (ID): BTN Matalawa.

Friday KS, Drilling ME, Garrity DP. 2000. Rehabilitasi Padang Alang-alang Menggunakan Agroforestry dan Pemeliharaan Permudaan Alam. Bogor (ID): ICRAF.

Gbetoho AJ, Aoudji AKN, Roxburgh L, Ganglo JC. 2017. Assessing the suitability of pioneer species for secondary forest restoration in beninin the context of global climate change. Bois Et Forets Des Tropiques. 332(2): 43-55.

Hardiyanto EB. 2008. Seed Collection and HandlingPutat (Planchonia valida) (Blume) Blume. Bali (ID): ITTO.

Haryanti S. 2008. Respon pertumbuhan jumlah dan luas daun nilam (Pogostemon cablin (Benth) pada tingkat naungan yang berbeda. Buletin anatomi dan fisiologi. 16(2): 20-26.

Hidayat O, Kayat. 2014. Karakteristik dan preferensi habitat kakaktua sumba (Cacatua sulphurea citrinocristata) di Taman Nasional Laiwangi Wanggameti Provinsi Nusa Tenggara Timur. Widyariset. 17(3): 399-408.

Hooper ER, Legendre P, Condit RS. 2005. Barriers to forest regeneration of deforested and abandoned land in Panama. Journal of Applied Ecology. 42: 1165-1174.

Kalima T. 2008. Profil keragaman dan keberadaan spesies dari suku dipterocarpaceae di Taman Nasional Meru Betiri, Jember. Jurnal Penelitian Hutan dan Konservasi Alam. 5(2): 175-191.

Lamb D, Gilmour D. 2003. Rehabilitation and Restoration of Degraded Forests. Cambridge (UK): IUCN.

Lestari T, Abdi Z, Widodo J, Yohanes. 2008. Analisis vegetasi di lahan bekas penambangan timah Desa
Rebo, Kabupaten Bangka. Enviagro, JurnalPertanian. 2(2): 1-28.

Mayakawa H, Darsono, Okabe H, Desitarani, Ibnu Z, Sitorus RH, Yuliani M, Dewitri C, Nurhadi, Susyafrianto J et al. 2014. Pedoman Tata Cara Restorasi di Kawasan Konservasi: Hutan Hujan Tropis Pegunungan dan Hutan Monsoon Tropis. Jakarta (ID): JICA.

Munawar A. 2011. Kesuburan Tanah dan Nutrisi Tanaman. Bogor (ID): IPB Press.

Price G. 2006. Australian Soil Fertility Manual. $3^{\text {rd }}$ Ed. Collingword (AU): CSIRO Publishing.

Pudjiharta A, Widyati E, Adalina Y, Syafrudin HK. 2008. Kajian teknik rehabilitasi lahan alang-alang (Imperata cylindrical. Beauv). Info Hutan. 5(3): 219-230.

Queensland Government. 2006. Nature Conservation (Wildlife) Regulation. Queensland (AU): Queensland Government.

Sarwono J. 2006. Metode Penelitain Kuantitatif dan Kualitatif. Yogyakarta (ID): Graha Ilmu.

Shadily H. 1984. Ensiklopedi Indonesia Jilid ke-5. Jakarta (ID): Ictiar Baru- Van Hoeve dan Elsevier Publishing Projects.

Solichatun, Anggarwulan E, Mudyantini W. 2005. Pengaruh ketersediaan air terhadap pertumbuhan dan kandungan bahan aktif saponin tanaman ginseng jawa (Talinum paniculatum Gaertn.). Biofarmasi. 3(2): 47-51.

Takeuchi W. 2000. Additions to the flora of Crater Mt., Papua New Guinea. Sida Contributions to Botany. 19(2): 237-239.

Wagner WL, Herbst DR, Sohmer SH. 1999. Manual of the Flowering Plants of Hawai'i. 2 vols. Hawai (US): Bishop Museum Special Publication 83, University of Hawai'i and Bishop Museum Press.

Walpole RE. 1995. Pengantar Statistik. Jakarta [ID]: Gramedia Pustaka Umum.

Widya A, Hikmat A, Kartono AP. 2015. Etnobotani dan konservasi ketimunan /Timonius timon (Spreng.) Merr. pada masyarakat lokal Suku Kanume di Taman Nasional Wasur Papua. Media Konservasi. 20(2): 149-158. 